
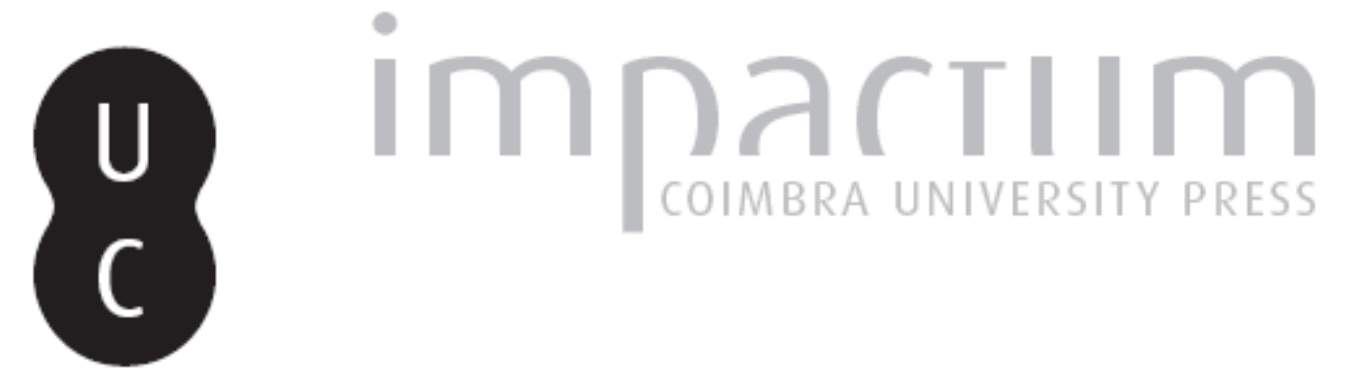

\title{
A imposição do medo do direito penal como instrumento de gestão dos setores subalternos da população Brasilieira
}

\author{
Autor(es): $\quad$ Wermuth, Maiquel Ângelo Dezordi \\ Publicado por: Universidade Católica de Petrópolis \\ URL \\ persistente: \\ URI:http://hdl.handle.net/10316.2/33825 \\ DOI: \\ DOI:http://dx.doi.org/10.14195/2175-0947_2-2_2
}

Accessed : $\quad$ 26-Apr-2023 11:01:49

A navegação consulta e descarregamento dos títulos inseridos nas Bibliotecas Digitais UC Digitalis, UC Pombalina e UC Impactum, pressupõem a aceitação plena e sem reservas dos Termos e Condições de Uso destas Bibliotecas Digitais, disponíveis em https://digitalis.uc.pt/pt-pt/termos.

Conforme exposto nos referidos Termos e Condições de Uso, o descarregamento de títulos de acesso restrito requer uma licença válida de autorização devendo o utilizador aceder ao(s) documento(s) a partir de um endereço de IP da instituição detentora da supramencionada licença.

Ao utilizador é apenas permitido o descarregamento para uso pessoal, pelo que o emprego do(s) título(s) descarregado(s) para outro fim, designadamente comercial, carece de autorização do respetivo autor ou editor da obra.

Na medida em que todas as obras da UC Digitalis se encontram protegidas pelo Código do Direito de Autor e Direitos Conexos e demais legislação aplicável, toda a cópia, parcial ou total, deste documento, nos casos em que é legalmente admitida, deverá conter ou fazer-se acompanhar por este aviso.

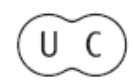



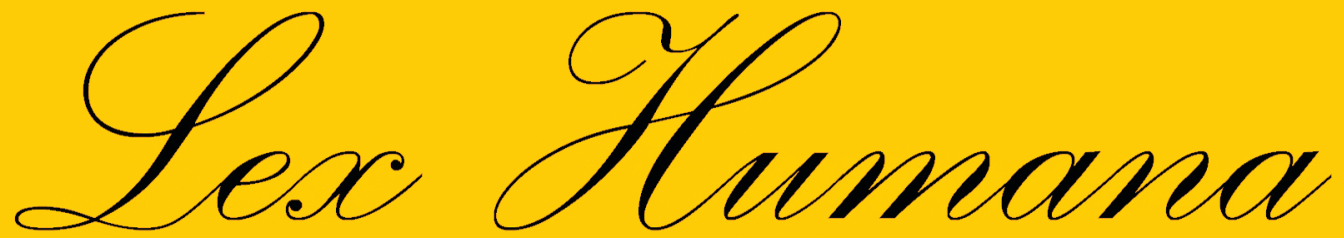

Revista do Programa de Pós-Graduação em Direito da UCP

ISSN(e) 2175-0947

Universidade Católica de Petrópolis Rua Benjamin Constant, 213 - Petrópolis - Centro CEP 25610-130

Tel: (24) 2244-4000 E-mail: lexhumana@ucp.br 


\section{A Imposição do Medo do Direito PenAl COMO Instrumento de Gestão dos Setores Subalternos DA População BRASILIEIRA}

Maiquel Ângelo Dezordi Wermuth ${ }^{1}$

Resumo: O artigo analisa, a partir da perspectiva histórica, a imposição do medo do Direito Penal aos setores subalternos da sociedade brasileira, de forma a contribuir, por um lado, para a manutenção da violência estrutural inerente ao modelo de formação dessa sociedade, pautado no autoritarismo e na submissão dos desvalidos à vontade dos detentores do poder econômico, e, por outro, a garantir a imunização penal dos grupos sociais que ocupam, nesta estrutura, espaços privilegiados de poder. Ou seja, procura-se demonstrar que o medo do Direito Penal, ainda hoje serve como instrumento de reprodução da configuração de relações sociais excludentes e autoritárias que estão enraizadas na sociedade brasileira.

Palavras-chave: Direito Penal. Medo. Seletividade. Exclusão social.

Abstract: The article examines, from a historical perspective, the imposition of fear on criminal law to the subaltern sectors of Brazilian society in order to contribute, on one hand, on the maintenance of the structural violence inherent in the training model of the company, based on authoritarianism and submission of the disadvantaged

1 Advogado. Mestre em Direito Público pela UNISINOS - Universidade do Vale do Rio dos Sinos. Professor do Curso de Graduação em Direito da UNIJUÍ - Universidade Regional do Noroeste do Estado do Rio Grande do Sul. E-mail: madwermuth@,gmail.com. 
people by the holders of the economic power, and, by the other hand, to ensure the immunization of criminal groups which occupy, in this structure, privileged spaces of power. That is, it is demonstrated that the fear on criminal law is still used as an instrument to reproduce the configuration of exclusionary and authoritarian social relations that are rooted in Brazilian society.

Key-words: Penal Law. Fear. Selectivity. Social Exclusion

\section{CONSIDERAÇÕES INICIAIS}

A partir da análise de dois momentos históricos fundamentais da história nacional pretende-se demonstrar como o medo do Direito Penal opera no Brasil como instrumento de controle e disciplina social das classes populares que vão de encontro aos interesses das hegemonias conservadoras. O primeiro momento analisado é o período pós-abolição da escravatura, quando se busca implantar no país, a partir da Proclamação da República, a ordem burguesa fazendo surgir a figura do "malandro" ou "vadio" para representação e identificação dos "inimigos" da "ordem e do progresso". O segundo momento contextualizado inicia no período no qual se começa a implementar no país o modelo neoliberal, notadamente a partir da década de 80 do século XX, estendendo-se até os dias atuais quando, mesmo tendo por norte a persecução à macrocriminalidade representada pela figura do "traficante", o sistema penal brasileiro deixa clara a cada intervenção a sua seletividade, justificando, por meio de uma suposta defesa da sociedade em face deste tipo de crimes, 
a sua atuação truculenta em relação àqueles que são historicamente perseguidos pelo "braço armado" do Estado brasileiro.

A escolha destes dois períodos históricos decorre da compreensão de que, dentro da periodização estabelecida por Batista (2002) - segundo o qual se pode distinguir quatro sistemas penais brasileiros, quais sejam: o colonial-mercantilista, o imperial-escravista, o republicano-positivista e o contemporâneo, denominado pelo autor de sistema penal do capitalismo tardio -, são os dois últimos que permitem demonstrar de forma mais transparente como o sistema penal opera de modo seletivo contra os espólios da escravidão, revelando-se, nesse ponto, o verdadeiro e real poder por ele exercido, qual seja, o seu poder positivo, configurador da realidade social.

Considerando o exposto, serão abordados os principais aspectos dos "sistemas penais" brasileiros, com ênfase nos dois acima indicados, de forma a demonstrar como a figura do "vadio" da incipiente república (tópico 2) transmutou-se, na contemporaneidade, na figura do "traficante" (tópico 3), legitimando, assim, o incremento da antiga truculência do sistema punitivo nacional - por meio inclusive de estratégias de construção imagética do terror (tópico 4) - contra sua clientela habitual: as camadas subalternas da população.

\section{A DISCIPLINA DOS CORPOS INDÓCEIS NA CONSTRUÇÃO DA ORDEM BURGUESA NO BRASIL}

Os sistemas penais denominados por Batista (2002) de colonial-mercantilista e imperial-escravista foram marcados por uma intervenção punitiva que se dava sobre o próprio corpo da sua clientela, composta precipuamente pelos escravos e trabalhadores livres pobres. A compreensão do público como uma mera continuação do privado - decorrente da tradição ibérica denominada por Max 
Weber (1999) de patrimonialismo - significava uma intervenção punitiva pública pautada nas práticas penais do espaço do senhor.

Com efeito, a estrutura descentralizada com que se dava o exercício do poder dos senhores proprietários de terras instituiu espaço profícuo para a implantação de tiranias privadas, uma vez que a autoridade dos senhores escravocratas era absolutamente inquestionável: "tudo se fazia consoante sua vontade, muitas vezes caprichosa e despótica." (HOLANDA, 2007, p. 80). A própria justiça estatal tinha um alcance limitado, dado que "o poder do governo terminava na porteira das grandes fazendas" (CARVALHO, 2003, p. 21), onde o senhor imperava absoluto.

Ou seja, no período colonial, como salienta Batista (2002), as Ordenações Manuelinas (datadas de 1521) e Filipinas (datadas de 1603) constituíam apenas um pano de fundo para o exercício pouco e às vezes não regulamentado - do poder punitivo que era delegado aos donatários pelo rei.

Com a independência do País, segundo Carvalho (2003), não se introduziu nenhuma mudança radical na sua estrutura política e na sua forma de organização social, justamente em virtude da força da cultura política colonial e do fato de que o processo de declaração da independência foi conduzido de forma bastante pacífica, uma vez que foi resultado de negociações entre a elite brasileira, a Coroa portuguesa e a Inglaterra. O povo assumiu, nesse processo, uma postura de simples espectador, tanto que a notícia da independência só chegou a alguns lugares meses depois da sua declaração. Para o referido autor (2003, p. 28), "a tranqüilidade da transição facilitou a continuidade social."

E a já referida "invasão" do público pelo privado, em que pese ser fruto do período em que a sociedade brasileira ainda era essencialmente rural, não foi suplantada com o processo de 
urbanização do País iniciado a partir da declaração da independência. Isso porque, com a formação dos centros urbanos, os cargos relativos à vida citadina (carreiras burocráticas, profissões liberais, etc) foram sendo paulatinamente ocupados pelos próprios aristocratas rurais e seus descendentes que, transportados para as cidades, carregaram consigo "a mentalidade, os preconceitos e, tanto quanto possível, o teor de vida que tinham sido atributos específicos de sua primitiva condição." (HOLANDA, 2007, p. 82).

No que tange à legislação penal do período imperial, destacase a inspiração liberal do Código Criminal de 1830, sob inspiração de brasileiros que estudavam Direito em Coimbra onde tiveram contato com obras dos iluministas e tentaram transportar para o país dito ideário. No entanto, como a base da economia brasileira permanecia sendo a monocultura latifundiária sustentada pela mão-de-obra escrava, verifica-se que o referido Código, em que pese a inspiração iluminista, não representou uma significativa modificação no que tange aos instrumentos de punição das camadas representadas pelos escravos e pelos homens livres e pobres.

A propósito, deve-se destacar que a Constituição de 1824, outorgada pelo imperador, não contemplava em seus dispositivos "o escravo ou o homem livre e pobre, mas apenas aqueles que, a partir de rendas estipuladas, teriam acesso aos diferentes níveis de participação política", ao passo que o Código Criminal "abrangia todos os segmentos sociais." (NEDER, 2007, p. 185). Assim, mesmo sob a influência ideológica do liberalismo, o Código Criminal de 1830 mantinha um sistema de penas cruéis voltado precipuamente aos escravos, com destaque para a manutenção da pena de açoite prevista no seu artigo 60, "humanizada" no que diz respeito à limitação do número de açoites, cujo número máximo não poderia ultrapassar o de cinquenta por dia/escravo. 
É por isso que os bacharéis brasileiros da época, em que pese a "contaminação" ideológica de cariz iluminista decorrente da sua formação, representavam, na visão de Neder (2007, p. 187-188), “os expoentes de uma classe que se sustentou à base do açoite, no controle social direto e repressivo do cotidiano dos escravos", razão pela qual afirma a sobredita historiadora (2007, p. 191) que, mesmo parecendo, à primeira vista, que se buscava com a Constituição de 1824 e o Código Criminal de 1830 negar a herança colonial e rural, "toda a estrutura política e jurídica do Império permaneceu fundada nas mesmas bases anteriores: o latifúndio agro-exportador e o trabalho escravo."

Estabelece-se, assim, com a transposição dos ideais liberais para o domínio brasileiro, a seguinte equação: afirmação dos direitos de liberdade para as classes dominantes versus manutenção da opressão sobre os setores subalternos, como decorrência da manutenção do trabalho escravo como base de sustentação da elites.

Com as rupturas significativas ocorridas no Brasil entre os séculos XIX e XX, representadas pelo fim do trabalho escravo (1888) e do regime monárquico (1889), houve reflexos na forma como se estruturou o controle social sobre as camadas vulneráveis da população.

De acordo com Neder (2009, p. 18), a partir de então,

exige-se modernização técnica e de procedimentos para punição, seguindo os ventos das inovações aplicadas pelas políticas liberalizantes relativas aos direitos (de cidadania e direitos humanos) nas formações históricas das duas margens do Atlântico, desde fins do século XVIII; e, ao mesmo tempo, quer-se uma política de controle e disciplinamento das classes populares rígida, 
autoritária e altamente repressiva.

Verifica-se, portanto, uma interpenetração do ideário burguês com permanências históricas da cultura política do Antigo Regime e do escravismo, "que deu suporte a uma prática jurídico-política e a uma afetividade absolutista, que desafiaram a racionalidade do capitalismo e seu ideário, que se queria implantar." (NEDER, 2009, p. 20).

Constata-se, assim, nesse período, um certo afinamento das elites brasileiras com a política européia de organização da justiça criminal (modernização, ainda que conservadora), mas a estrutura social até pouco tempo calcada na escravidão segue sendo responsável pela manutenção de mecanismos arcaicos de manutenção do poder destas elites.

O cotejo entre o Código Penal republicano de 1890 e a Constituição de 1891 deixa clara essa dinâmica: ao passo que o primeiro foi marcado por traços eminentemente repressivos, em especial no que diz respeito aos chamados "Crimes contra a liberdade de Trabalho", a segunda foi informada por princípios liberais, o que resta claro a partir da leitura dos dispositivos referentes à declaração dos direitos dos cidadãos. Quer dizer, à inclusão na cidadania por meio da Carta Constitucional correspondia a exclusão por meio do Código Penal sempre que estivesse ameaçada a "liberdade de trabalho" (NEDER, 1995).

Além disso, deve-se atentar para o fato de que o surgimento de um Código Penal em momento anterior à Constituição republicana evidencia, como observa Flauzina (2008, p. 82) que “o fim do regime de trabalhos forçados reclamou prioritariamente um instrumento de repressão, deixando para segundo plano uma carta de declaração de direitos e princípios que regulamentasse a vida em sociedade." 
Torna-se possível, portanto, a afirmação de que a substituição do trabalho escravo pelo trabalho livre redundou na formação de uma estrutura de classes na qual a classe dominante - então representada pelas oligarquias cafeeiras ligadas à área mais dinâmica do ponto de vista econômico da sociedade brasileira da virada do século XIX para o século XX - procurou deter a manutenção do monopólio da repressão sobre as camadas inferiores - então representadas precipuamente pelos ex-escravos - e mesmo sobre os setores dominantes não hegemônicos, mantendo a "normalidade" e a "ordem" por meio do controle dos "desvios" (NEDER, 1995).

Nesse sentido, destaca Chalhoub (2001, p. 67) que "a lei de 13 de maio era percebida como uma ameaça à ordem porque nivelava todas as classes de um dia para o outro, provocando um deslocamento de profissões e de hábitos de conseqüências imprevisíveis." É por isso que, segundo o autor (2001, p. 66-67), nos debates travados em 1888 na Câmara dos Deputados, a preocupação maior era com o combate à ociosidade, dada a compreensão de que "a Abolição trazia consigo os contornos do fantasma da desordem", sendo frequentes as reivindicações no sentido de uma maior proteção à propriedade e à própria segurança individual, "ameaçadas pelas 'hordas' de libertos que supostamente vagavam pelas estradas a 'furtar e rapinar'."

O pano de fundo destes debates era o consenso firmado quanto ao caráter dos libertos,

em geral pensados como indivíduos que estavam despreparados para a vida em sociedade. A escravidãonãohavia dadoaesses homensnenhuma noção de justiça, de respeito à propriedade, de liberdade. A liberdade do cativeiro não significava para o liberto a responsabilidade pelos seus atos, 
e sim a possibilidade de se tornar ocioso, furtar, roubar etc. [...] Esses vícios seriam vencidos através da educação, e educar libertos significava criar o hábito do trabalho através da repressão, da obrigatoriedade. (CHALHOUB, 2001, p. 68).

Para tanto, precisava-se de uma justificação ideológica para o trabalho obrigatório para as classes populares, a qual vai ser buscada a partir da concepção do trabalho enquanto elemento de ordenação da sociedade, sendo uma retribuição, pelo trabalhador, à sociedade, de tudo aquilo que ela lhe garante, a exemplo da segurança, dos direitos individuais, da liberdade, etc. Outrossim, estabelece-se um liame entre trabalho e moralidade, pautado na compreensão de que quanto maior a dedicação do indivíduo ao trabalho, maiores os seus atributos morais (CHALHOUB, 2001).

É exatamente em virtude disso que o Código Penal brasileiro promulgado em 1890, ou seja, dois anos após a abolição da escravidão, exerceu, na falta de uma legislação que regulasse as relações de trabalho entre as classes dominantes e subalternas, a função de Direito do Trabalho, com um viés repressivo e autoritário (NEDER, 1995; NEDER e CERQUEIRA FILHO, 2006).

Com efeito, o fato de o Brasil viver um momento de constituição de um mercado de trabalho "livre" no bojo do processo de implantação do capitalismo no país, redundou na ênfase dada ao ideal burguês do trabalho. O indivíduo, neste contexto, ou era trabalhador ou era vadio e, consequentemente, perigoso, devendo, portanto, ser reprimido.

Sobre essa preocupação com o "combate à ociosidade", Chalhoub (2001, p. 65) salienta que a transição do trabalho escravo para o trabalho livre implicou uma necessidade de reajustamento 
do universo mental das elites dominantes no que diz respeito à questão do trabalho, uma vez que, com a escravidão, dita questão era escassamente problematizada, uma vez que os senhores eram proprietários dos escravos. Portanto, "o mundo do trabalho estava obviamente circunscrito à esfera mais ampla do mundo da ordem, que consagrava o princípio da propriedade."

No entanto, com a abolição da escravidão, impossibilitou-se o suprimento de força de trabalho aos empreendimentos econômicos por meio da propriedade dos escravos, colocando-se, então, o grande problema: transformar o liberto, dono de sua força de trabalho, em um trabalhador disposto a vender sua capacidade laboral ao capitalista empreendedor, de forma a continuar a acumulação de riquezas dos senhores/patrões (CHALHOUB, 2001).

Deve-se salientar, ainda, de acordo com Neder e Cerqueira Filho (2006), que a extinção do tráfico negreiro, em 1850, representou um fator de estabilização demográfica da massa escrava, o que implicou uma longevidade maior dessa população. Como decorrência disso, surge a Lei dos Sexagenários, em 1885, que colocou em liberdade os velhos escravos, os quais passaram a engrossar as fileiras de mendigos e indigentes nas cidades brasileiras, aumentando assim os protestos e a revolta escrava.

O referido quadro agravou-se com a abolição da escravidão, quando os ex-escravos, embora disponíveis ao mercado de trabalho livre, foram excluídos da maioria das profissões que exigiam um certo grau de alfabetização/qualificação, sendo-lhes reservados "trabalhos vis, mal pagos e sem promessas de ascensão social." (NEDER e CERQUEIRA FILHO, 2006, p. 28). Ou seja, "o negro passou de escravo a trabalhador livre, sem mudar, contudo, sua posição relativa na estrutura social." (CHALHOUB, 2001, p. 88).

Outro fator que contribuiu para a exclusão social da população 
negra foi a imigração européia: as classes dominantes viam o negro como um mau trabalhador, ao passo que no imigrante branco enxergavam uma possibilidade de aceleração da transição para o sistema capitalista, razão pela qual os empreendedores da época, ao contratarem trabalhadores, assumiam posturas discriminatórias em detrimento dos negros. Ademais, o fomento da imigração representava o "embranquecimento" da população nacional, ou seja, fator preponderante para o progresso diante da compreensão da raça branca como superiora e da raça negra como degenerada e, portanto, um entrave para o desenvolvimento nacional (CHALHOUB, 2001).

Diante desse quadro, verifica-se que as medidas repressivas da época voltavam-se, por um lado, para a imposição da ideologia burguesa do trabalho, e, por outro, para o controle e a disciplina da população ex-escrava. Na verdade, o primeiro objetivo servia como instrumento de encobrimento ideológico do segundo, afinal, foi aquilo a que Chalhoub $(1996 ; 2001)$ denomina de "medo branco" que se instaurou no país no período pós-abolição - decorrente do medo de uma possível insurreição negra diante das precárias condições de vida na qual viviam as massas ex-escravas - que dirigiu as estratégias antecipatórias da afirmação de uma codificação penal repressiva. $\mathrm{O}$ medo das elites de perder "as rédeas do controle sobre a população negra", destaca Flauzina (2008, p. 82), "passou a ser a plataforma principal das investidas de cunho repressivo."

Como assevera Malaguti Batista (2003a, p. 37),

esse medo branco que aumenta com o fim da escravidão e da monarquia produz uma República excludente, intolerante e truculenta com um projeto político autoritário. Essa foi sempre a síndrome do liberalismo oligárquico brasileiro, 
que funda a nossa República carregando dentro de si o princípio da desigualdade legítima que herdara da escravidão.

Com efeito, como destaca Neder (2007, p. 184), a "fantasia absolutista" da possibilidade de um controle absoluto de tudo e de todos não foi processada no Brasil nem mesmo com a abolição da escravidão e a instituição da república:

persistimos, no Brasil, com um legado, uma herança do absolutismo português, com a fantasia absolutista do controle social (policial) absoluto sobre os espaços urbanos (na verdade, o controle absoluto sobre a massa de ex-escravos, de seus descendentes afro-brasileiros, e de trabalhadores urbanos, de um modo geral). Donde a ênfase nas campanhas de lei e ordem, ainda discutidas e implementadas pelas polícias no Brasil no tempo presente.

Cumpre salientar que todo o discurso jurídico brasileiro da época buscava legitimidade no pensamento europeu, onde a Criminologia emergia enquanto ciência, com o escopo de, por meio de um discurso dotado de cientificidade - ao lado da Sociologia e da Psicologia -, garantir a hegemonia burguesa em face do movimento operário europeu. Em terrae brasilis, as teses então propaladas pela Criminologia europeia, em especial aquelas que sofriam influência do racismo-biologista de corte epistemológico lombrosiano, foram assimiladas e reelaboradas, fazendo surgir o "criminoso brasileiro", o qual "ganhou novos adereços, relacionados às teses da miscigenação 
racial e às elucubrações sobre a presença de ex-escravos de origem africana nas cidades brasileiras." (NEDER e CERQUEIRA FILHO, 2006, p. 27).

É, portanto, da soma desses fatores - necessidade de imposição do "controle" da população de ex-escravos por meio do trabalho e "medo branco" de uma possível insurreição negra - que, à luz da criminologia racista-biologista "à la brasileira", surge a figura do "malandro", ou seja, do "vadio", como primeira figura perseguida majoritariamente pelo sistema punitivo brasileiro (NEDER, 1995). É por isso que o Código Penal de 1890 tipifica como crime, em seu artigo 399, a vadiagem, e, no artigo 206, criminaliza a greve.

Ou seja, a tipificação da vadiagem e da greve representa uma tentativa das classes dominantes da época de impor àquela população, por meio do Direito Penal, a "ordem social". A criminalização da vadiagem representa uma individualização das manifestações consideradas "contrárias à ordem", perpetradas precipuamente pela população de ex-escravos, admitidas em um espaço bastante restrito do mercado de trabalho. Ademais, com a criminalização da vadiagem e da greve busca-se disciplinar os corpos dos trabalhadores - agora livres - para o trabalho fabril, diante do estabelecimento de uma economia de mercado.

Portanto, pode-se afirmar que "a penetração da idéia de trabalho, no quadro de estruturação da sociedade de classes, surgiu acompanhada de seu par contrário: a malandragem, que envolveu aqueles que não se enquadraram na nova ordem." (NEDER e CERQUEIRA FILHO, 2006, p. 29).

Merece atenção, no entanto, o fato de que a ociosidade só era vista como um aspecto negativo - e portanto digno de repressão quando associada à pobreza, uma vez que o ocioso que possuísse meios de garantir sua subsistência não era considerado um perigo à 
ordem social. Diferente, no entanto, é o caso da união da ociosidade à pobreza, que afetam o senso moral, deturpam o ser humano e conduzem à criminalidade. É por isso que Chalhoub (2001, p. 75) salienta existirem "uma má ociosidade e uma boa ociosidade": a primeira, por ser característica das classes pobres, merece repressão, ao passo que a segunda, por ser características das elites, é compreendida como um "atributo".

Portanto, a tipificação da vadiagem visava, por um lado, garantir que, mesmo com a abolição da escravidão, os negros continuassem sujeitos ao trabalho, e, por outro, garantir o controle dessa população, por meio da "estratégia da suspeição generalizada, com os afro-brasileiros vistos como suspeitos preferenciais." (MALAGUTI BATISTA, 2003a, p. 38).

É dessa época o surgimento no debate parlamentar brasileiro do conceito de "classes perigosas" enquanto sinônimo de "classes pobres", demonstrando a compreensão de que "o fato de ser pobre torna o indivíduo automaticamente perigoso à sociedade", uma vez que "os pobres apresentam maior tendência à ociosidade, são cheios de vícios, menos moralizados e podem facilmente 'rolar até o abismo do crime'." (CHALHOUB, 2001, p. 76).

A partir da análise da destruição, comandada pelas autoridades da época, do cortiço Cabeça de Porco, na cidade do Rio de Janeiro, em 1893, Chalhoub (1996) analisa como se deu o surgimento do conceito de "classes perigosas" como sinônimo de "classes pobres" no Brasil. A origem da expressão "classes perigosas" é buscada pelo referido autor $(1996$; 2001) na obra da autora inglesa Mary Carpenter, que compreendia nesta terminologia aquelas pessoas que já tivessem entrado em contato com o sistema penal, ou mais especificamente com a prisão, em decorrência do fato de terem optado por obter o sustento próprio e de suas famílias por meio de delitos contra o patrimônio e 
não por meio do trabalho.

No Brasil, os parlamentares do período histórico enfocado, inspirados pela leitura de autores europeus, dão à concepção restrita de classes perigosas esboçada por Mary Carpenter um alargamento que vai ao encontro de suas preocupações com a "ociosidade" dos exescravos, fonte frequente de riscos e insegurança para as elites.

A pobreza e a (má) ociosidade, portanto, são os dois grandes problemas a serem combatidos à época da implantação da ordem burguesa no País, como pressuposto para a "ordem e o progresso", considerando-se o risco que essa "soma" apresentava para a sociedade. O mundo da ociosidade e do crime, no universo ideológico das classes dominantes brasileiras no ocaso do regime monárquico e durante a República Velha, encontra-se em posição diametralmente oposta ao mundo do trabalho e da virtude, ou seja, da ordem. É por isso que a repressão à ociosidade é eleita como estratégia primeira de manutenção da ordem.

Portanto, o medo de uma possível insurreição por parte dos setores subalternos da população passou a ser combatido por meio da imposição do medo do Direito Penal, instrumento de controle e disciplina. Afinal, a eficácia das instituições de controle social destaca Neder (1995, p. 33) - "se funda na capacidade de intimidação que estas são capazes de exercer sobre as classes subalternas, mais propensas a cometer 'delitos'."

Assim, a equiparação conceitual equivocada traçada pelas elites do período enfocado entre "pobreza" e "periculosidade" serve como fundamento para, a partir da constatação da pobreza de um indivíduo, inferir sua potencial periculosidade e, portanto, a necessidade de seu constante controle por parte do aparato penal estatal.

E o fato de alguns cidadãos serem considerados "mais 
suspeitos" do que outros decorre justamente da posição subalterna ocupada pelas massas ex-escravas no período, a demonstrar que o fato de o surgimento do conceito de "classes perigosas" como sinônimo de "classes pobres" coincidir com o período pós-abolição não é, na verdade, pura coincidência, mas decorre justamente de uma necessidade maior de justificar o controle dessa população, já que estava inviabilizado o recurso às políticas de dominação típicas do cativeiro. A "teoria" da "suspeição generalizada" - na expressão de Chalhoub (1996) e Malaguti Batista (2003a) - é então utilizada para levar a cabo esse controle.

É exatamente essa suspeição generalizada, portanto, que passa a legitimar a histeria das primeiras administrações republicanas no que tange ao controle dos espólios da escravidão, razão pela qual afirma Flauzina (2008, p. 88), que o sistema penal da Primeira República, "como toda a burocracia estatal, cultiva o saudosismo da 'segurança' dos tempos do escravismo."

Torna-se, assim, possível a afirmação de que as raízes ibéricas do sistema jurídico-penal brasileiro são responsáveis pela criação de uma estrutura punitiva voltada precipuamente contra os setores subalternos da população, considerados enquanto ameaça constante à "ordem" imposta pelos setores dominantes. Os mecanismos de punição privados levados a cabo pelos senhores de escravos para submissão forçada destes ao trabalho, nesse sentido, representam o modelo a ser seguido pelo controle social formal que será instituído no Brasil.

Portanto, o sistema punitivo brasileiro já nasce com uma missão bem definida: segregação e, sempre que esta for insuficiente, eliminação dos riscos representados pela existência das classes perigosas, missão esta que vai seguir imutável por todo o período histórico subsequente e que será implementada com o advento das 
reformas neoliberais operadas no País no final do século XX e albores do século XXI, como se demonstrará a seguir.

\section{A IMPOSIÇÃO DO MEDO DO DIREITO PENAL E A IMPLANTAÇÃO (E MANUTENÇÃO) DO MODELO NEOLIBERAL}

De acordo com Neder e Cerqueira Filho (2006), quando se analisam as instituições do sistema penal brasileiro, verifica-se que a cultura jurídica e política destas instituições não tem sofrido alterações substanciais desde a época da implantação da ordem republicana no país. A partir da década de trinta do século XX, em que pese a industrialização do país, verifica-se, no campo penal, reminiscências do período anterior. Isso fica claro, principalmente, a partir da análise do Código Penal de 1940 e do tecninicismo jurídico que lhe subjaz, o qual "circunscreve a atividade do jurista à elaboração e interpretação dos tipos penais." (FLAUZINA, 2008, p. 89). Ou seja, o tecnicismo jurídico incorporado pelo legislador penal de 1940 "isola o penalista numa torre de marfim", visto que tal expediente metodológico "não passa de um positivismo jurídico legitimador do sistema penal e cego perante seu real desempenho e suas funções." (BATISTA, 2002, p. 153).

Com isso, a questão da seletividade sócio-racial é "varrida para baixo do tapete", uma vez que o tecnicismo ínsito ao Código Penal de 1940 "promove a assepsia completa da raça no texto legal", razão pela qual, mesmo com uma "fachada de neutralidade e objetividade" no que diz respeito à criminalização primária que passa a ser assumida a partir de então, “a arquitetura punitiva elege as agências da criminalização secundária e os redutos da criminalização terciária, como os espaços para reprodução dos mandamentos da criminologia 
positivista" (FLAUZINA, 2008, p. 89) anunciada desde o nascimento da República, consoante explicitado no tópico precedente.

Portanto, mesmo com a "nova roupagem" assumida pelo sistema penal a partir do Código Penal de 1940, o projeto político que orienta a sua atuação segue sendo o mesmo desde a proclamação da República: o controle e o disciplinamento das classes populares - leiase "perigosas". A única mudança que se verifica é que a seletividade sócio-racial ínsita à atuação do sistema punitivo brasileiro, a partir da assepsia da raça no texto legal, tornou-se assunto tabu, diante da construção, a contar da década de vinte do século XX, do mito da existência, no Brasil, de uma "democracia racial" onde todos são iguais e coexistem na mais perfeita harmonia.

Como refere Flauzina (2008, p. 89-90),

se a enunciação do racismo foi vedada e todas as suas expressões mais nítidas foram jogadas para baixo do tapete, o discurso racista criminológico não poderia mais ser assumido de maneira aberta. Mesmo assim, seguiu vigoroso na orientação das práticas punitivas na direção dos corpos negros, pelo implícito do formalmente aceito, o subterrâneo das práticas inconfessáveis.

Enfim, como aduz Zaffaroni (2001, p. 40), mesmo não existindo uma formulação teórica latino-americana que explicite publicamente esta tese, expressa-se com sinceridade - mas em voz baixa - em quase todos os círculos acadêmicos que "a lei é boa para conter os excessos, mas só a lei não nos leva a nada porque não se pode acabar com os negros."

Portanto, o tecnicismo jurídico característico do Código Penal 
de 1940 demonstra que nenhuma mudança radical se operou em relação à seletividade do sistema punitivo brasileiro. Pelo contrário, apenas torna possível a constatação de que ele está estruturalmente montado para atuar de forma seletiva, uma vez que seus "órgãos executivos têm 'espaço legal' para exercer poder repressivo sobre qualquer habitante, mas operam quando e contra quem decidem." (ZAFFARONI, 2001, p. 27).

Em razão disso, pode-se asseverar, de acordo com Andrade (1997), que a tipificação da conduta delituosa não se exaure no momento normativo, nem tampouco a aplicação da norma ao caso concreto constitui um exercício de mera lógica formal; pelo contrário, a lei penal configura um marco abstrato de decisão dentro do qual as agências do sistema penal gozam de uma ampla margem de discricionariedade. Destarte, trata-se de suposição errônea aquela propalada pelo discurso jurídico-penal segundo a qual a prática da infração penal enseja a aplicação automática da pena, isto porque "entre a seleção abstrata, potencial e provisória operada pela lei penal e a seleção efetiva e definitiva operada pelas instâncias de criminalização secundária [polícia, Ministério Público, Poder Judiciário, etc], medeia um complexo e dinâmico processo de refração." (ANDRADE, 1997, p. 260).

Esta seleção quantitativa levada a cabo pelo sistema penal foi revelada principalmente a partir do novo papel relegado ao estudo das estatísticas criminais pela Criminologia Crítica, em especial no que tange à questão da criminalidade de colarinho branco e da cifra oculta da criminalidade. As estatísticas criminais sempre serviram como ponto de apoio das investigações criminológicas, uma vez que revelam a atividade da polícia, do Ministério Público, dos Tribunais e das instituições penitenciárias no "combate à criminalidade". No entanto, com a revelação da criminalidade de colarinho branco e 
da cifra oculta da criminalidade, passou-se a duvidar do valor de verdade das estatísticas criminais no que pertine à quantificação da criminalidade "real", afinal, constatou-se que "nem todo delito cometido é perseguido; nem todo delito perseguido é registrado; nem todo delito registrado é averiguado pela polícia; nem todo delito averiguado é denunciado; nem toda denúncia é recebida; nem todo recebimento termina em condenação." (ANDRADE, 1997, p. 262-263).

Assim, antes de se apresentarem como fonte de estudo da criminalidade em si, as estatísticas criminais transformaram-se em um hábil instrumento para a investigação da lógica do controle social levado a cabo pelo sistema penal, uma vez que, a partir da constatação de que elas representam a criminalidade - em especial aquela praticada por pessoas de alto prestígio social, ou seja, a de colarinho branco - de um modo muito inferior à sua cifra oculta, foi possível demonstrar que as sobreditas estatísticas acabam por distorcer a distribuição da criminalidade nos grupos sociais. Em função disso, cria-se uma falsa impressão de que ela é um atributo exclusivo das classes menos privilegiadas, legitimando, conseqüentemente, a atuação do sistema penal sobre tais estratos sociais (ANDRADE, 1997).

Ademais, ao revelar que a criminalidade real é infinitamente superior àquela apontada pelas estatísticas criminais, o estudo da sua cifra oculta permitiu chegar-se à conclusão fundamental de que a imunidade e não a criminalização é a regra no funcionamento do sistema penal e que todos os princípios ou valores sobre os quais o sistema se apoia (a igualdade dos cidadãos, a segurança, o direito à justiça, etc) são radicalmente deturpados, na medida em que só se aplicam àquele número ínfimo de situações que são os casos registrados, razão pela qual estes argumentos passaram a ser largamente utilizados pelas correntes abolicionistas, para as quais um sistema que rege apenas casos esporádicos é absolutamente 
desnecessário (HULSMAN, 1993).

Além da seletividade quantitativa do sistema penal, que deriva justamente de sua incapacidade operacional de seguir a planificação do discurso jurídico-penal, pode-se falar também em uma seletividade qualitativa, ou seja, pautada pela "especificidade da infração e as conotações sociais dos autores (e vítimas), isto é, das pessoas envolvidas." (ANDRADE, 1997, p. 266).

Com efeito, o fato de a clientela do sistema penal brasileiro ser composta quase que exclusivamente por pessoas pertencentes aos estratos sociais economicamente hipossuficientes - o que leva Flauzina (2008) a falar na monotonia cromática das massas encarceradas e dos corpos caídos no rastro da intervenção do sistema punitivo - demonstra que existe não um processo de seleção de condutas criminosas, mas sim de pessoas que receberão o rótulo de "delinquentes". Tal seletividade qualitativa deve-se ao fato de que, em sociedades desiguais, os grupos detentores da maior parcela do poder possuem a capacidade de impor ao sistema uma impunidade praticamente absoluta das suas próprias condutas criminosas, visto que "os tipos penais têm uma relação direta com os bens jurídicos que as camadas dominantes da sociedade pretendem preservar." (STRECK, 1998, p. 37).

Dado o caráter seletivo com que se dá a atuação das agências que integram o sistema penal, pode-se afirmar que o seu exercício de poder visa, antes do combate à criminalidade, à contenção de determinados grupos humanos que, diante configuração socioeconômica, traduzem-se em inconvenientes sociais. Essa seletividade é pautada em estereótipos que, geralmente associados às pessoas mais pobres, reforçam as desigualdades sociais, uma vez que operam claramente em benefício das pessoas que exibem os estigmas da respeitabilidade dominante e em desvalor dos que exibem os 
estigmas da associabilidade e do crime (ou seja, das chamadas "classes perigosas") (ANDRADE, 1997).

Destarte, o etiquetamento do indivíduo enquanto delinquente está intrinsecamente relacionado à posição social por ele ocupada, de forma que, segundo a lição de Baratta (2000, p. 32),

las personas vulnerables y sin ningún poder social que sufren lesiones de sus derechos económicos y sociales (derechos 'débiles', como señala la teoría de los derechos fundamentales), por parte del Estado o de la sociedade, se convierten de tal modo en potenciales agresores de los derechos fuertes (integridad física, derecho de propiedad) de los sujetos socialmente más protegidos.

Do até aqui exposto, torna-se possível afirmar que, no Brasil, se pune não para defender a sociedade do mal representado pela criminalidade, através da prevenção geral ou especial de novas condutas delitivas, mas sim para se conformar cada estrato social no lugar que lhe é atribuído pelo sistema de produção vigente e o código social por ele instituído.

Portanto, o Código Penal de 1940, em vigor por mais de cinco décadas, traz consigo, por trás da máscara de "neutralidade" do tecnicismo jurídico, toda a carga de preconceito racial ínsita à sociedade brasileira escravocrata, o que se revela precipuamente com a seletividade criminalizante do sistema punitivo que a partir dele se estrutura.

E com as reformas neoliberais que se verificam na sociedade brasileira nas últimas décadas, essa seletividade assume proporções incomensuráveis, visto que, a partir delas, somam-se à população 
historicamente perseguida pelo sistema punitivo na condição de espólio da escravidão os contingentes populacionais que são banidos do mercado de trabalho e da sociedade de consumo porque não dispõem de meios de participação efetiva. Ou seja, são consumidores falhos para os quais só resta a segregação, tanto pela via da marginalização social e espacial, quanto por meio do encarceramento em massa e da eliminação pura e simples a partir da intervenção violenta do sistema punitivo.

Vislumbra-se, portanto, uma substituição do Estado keynesiano por um modelo de Estado que Wacquant (2007, p. 31) denomina de "neo-darwinista", uma vez que se baseia na competição e celebra a responsabilidade individual irrestrita, tendo como contrapartida a irresponsabilidade coletiva, ou seja, política.

Neste sentido, alerta Streck (2008) para as consequências nefastas do "enxugamento" do Estado Providência em decorrência do avanço das políticas neoliberais em países que, como o Brasil, não tiveram um modelo de Estado tal. Para o autor (2008, p. 25-26), em decorrência justamente da grande desigualdade social ainda existente no Brasil, apresenta-se o seguinte dilema: "quanto mais necessitamos de políticas públicas, em face da miséria que se avoluma, mais o Estado, único agente que poderia erradicar as desigualdades sociais, se encolhe!"

Diante do quadro que se apresenta, verifica-se uma verticalização crescente do tecido social, a partir da qual os setores hegemônicos tendem a se tornar cada vez mais ricos, uma vez que desfrutam das oportunidades disponibilizadas pela ampliação dos mercados, enquanto os estratos economicamente hipossuficientes mergulham cada vez mais na miséria, o que é agravado pelo fato de estarem destituídos de sistemas públicos de proteção social.

Tem-se, portanto, a marginalização social de grandes contingentes populacionais, o que se torna flagrante a partir da 
análise dos cinturões de pobreza das grandes cidades brasileiras, que dispensa maiores esforços no sentido de demonstrar que há um projeto de expulsão da pobreza dos centros urbanos.

A estética das grandes cidades brasileiras demonstra que enquanto os bairros centrais são valorizados e se transformam em objeto de investimentos urbanísticos, as áreas marginais são caracterizadas pela crescente degradação, transformando-se em áreas de "risco" responsáveis por gerar um crescente e difuso sentimento de medo. A ampliação do número de integrantes das "classes perigosas" em decorrência da pauperização e do enxugamento do Estado de bem-estar - se é que é possível falar, no Brasil, em enxugamento de um modelo de Estado que nunca existiu -, e a sua acumulação em "áreas de risco", transforma-as em um "gigantesco Zumbi" - na expressão de Malaguti Batista (2003a) - que assombra a "civilização", legitimando "a engenharia de um controle penal cada vez mais sofisticado." (FLAUZINA, 2008, p. 99).

Esse controle das classes perigosas por meio do Direito Penal rearma-se diante do processo de expansão vivenciado por esse ramo do Direito diante dos "medos" da contemporaneidade, muitos deles frutos justamente da pauperização decorrente do esvaziamento do conteúdo social do Estado.

Diante desse contexto, "concentrar o medo numa parte da população que pode ser nomeada, reconhecida e localizada é absolutamente estratégico", uma vez que "parece não haver alternativa na administração do medo privatizado que leve às suas causas reais, que são difusas e globalizadas." (MALAGUTI BATISTA, 2003a, p. 97-98). Por isso, não causa espanto o fato de que, em uma sociedade como a brasileira, este "culpado" seja buscado dentre os setores subalternos, fonte inesgotável de insegurança desde os primórdios da história do País. 
Surgem, portanto, a partir do quadro esboçado, as novas "classes perigosas" brasileiras, compostas por aquelas pessoas que, segundo Bauman (2009, p. 22), passam a ser

consideradas incapacitadas para a reintegração e classificadas como não-assimiláveis, porque não saberiam se tornar úteis nem depois de uma "reabilitação". Não é correto dizer que estejam "em excesso": são supérfluas e excluídas de modo permanente (trata-se de um dos poucos casos permitidos de "permanência" e também dos mais ativamente encorajados pela sociedade "líquida").

São, portanto, os consumidores falhos os representantes atuais das classes perigosas, uma vez que são carecedores do dinheiro necessário para a inclusão e ao mesmo tempo criam uma demanda que não pode ser atendida de maneira lucrativa pela indústria do consumo, pois dependem de uma responsabilidade pública que cada vez mais se esvai. Ao passo que "os consumidores são os principais ativos da sociedade de consumo [...], os consumidores falhos são os seus passivos mais irritantes e custosos." (BAUMAN, 2005, p. 53).

A pobreza não configura mais uma reserva de mão-deobra barata. Ela é uma massa de indivíduos sem destino, porque absolutamente inúteis. São seres supérfluos e a possibilidade de sua inclusão é remota, o que os transforma em fontes de riscos para os incluídos. Afinal, "num mercado totalmente organizado em torno da procura do consumidor", em um contexto social onde o que importa é "manter essa procura permanentemente insatisfeita", criase como critério de "reordenamento" social "a aptidão e a capacidade de consumo", razão pela qual os consumidores falhos passam a 
ser considerados enquanto "novos impuros". É por isso que eles precisam ser segregados, inocuizados, afastados dos consumidores, enfim, destituídos de poder, de forma a manter incólume a "pureza da vida consumista" (MALAGUTI BATISTA, 2003a, p. 79).

Com isso, a fantasia absolutista de um controle absoluto dos corpos indóceis de que fala Neder $(1995 ; 2007)$ é repristinada na contemporaneidade a cada intervenção do sistema penal brasileiro sobre sua clientela preferencial. Não se pode olvidar, que, dentre as estratégias de que lançam mão as sociedades contemporâneas para tratar aquelas situações e/ou condutas que consideram indesejáveis, ofensivas ou ameaçadoras à "ordem", identificadas por Wacquant (2007, p. 21) como sendo a socialização, a medicalização ou a penalização dos conflitos sociais, esta última serve como instrumento de encobrimento ou invisibilização dos problemas sociais a respeito dos quais o Estado já não pode mais ou não se preocupa mais em tratar de forma mais profunda. Por essa razão, como já afirmado no capítulo precedente, a prisão passa a servir como "lata de lixo judiciária em que são lançados os dejetos humanos da sociedade de mercado."

Há, portanto, uma relação de complementaridade entre a destruição do Estado Social - que no Brasil não passou de um mero simulacro, como aduz Streck (2008) - e a hipertrofia do Estado Penal. Para Malaguti Batista (2003a, p. 79-80), “as políticas de segurança 'tolerância zero' e suas versões miméticas tupiniquins são prova viva disso, na busca da ordem urbana contra a impureza dos camelôs, flanelinhas e mendigos."

Com efeito, há no Brasil um modelo de ordenamento social onde à delinquência levada a cabo pelas classes perigosas é atribuído o papel de criação de medo e insegurança e "isto significa construir um consenso social através do medo e da insegurança visando a adoção de políticas repressivas e opressoras contra as classes populares e 
segmentos não-privilegiados." (DORNELLES, 2008, p. 37-38).

É necessário, portanto, impor o medo do Direito Penal, uma vez que a partir do momento em que o Estado se exime de suas tarefas de agente social do bem-estar, abre-se a necessidade de novas iniciativas do seu aparato repressivo em relação àquelas condutas transgressoras da "ordem" perpetradas pelos grupos que ameaçam esta "ordem". Outrossim, impõem-se iniciativas por parte do Estado que respondam às demandas das classes que se integram à esta "ordem" no sentido de se sentirem mais seguras em tal contexto (DORNELLES, 2008).

Nesse sentido, pode-se afirmar que o medo é gerenciado pelo empreendimento neoliberal no sentido de criar um ambiente propício para uma atuação do sistema penal pautada na administração, controle e eliminação dos setores da população em desafeto com os interesses hegemônicos, viabilizando a reprodução das assimetrias estruturais inerentes à formação da sociedade brasileira (FLAUZINA, 2008).

Nesse sentido, na contemporaneidade, pode-se afirmar que no Brasil o "crime organizado" e o "tráfico" representam as justificativas ideológicas de todo um processo de reforma legislativa em prol do recrudescimento punitivo em face deste tipo de criminalidade. No entanto, o que ocorre na realidade é que dito recrudescimento punitivo não opera contra a macrocriminalidade, mas incrementa a persecução penal às classes populares. Como destaca Batista (2002, p. 148),

o estatuto criminal da droga inventou um motivo fantasticamente plástico, capaz de substituir a guerra fria na realocação imperialista de continentes suspeitosos, capaz de conceder uma 
sobrevida à medicalização da conduta infracional que nem o positivismo criminológico mais estulto jamais imaginara, capaz de reinventar o sabá depois do iluminismo, porém principalmente capaz de alavancar doses gigantescas de vigilância e controle social penal sobre os filhos da pobreza, os únicos que se dispõem aos riscos letais que este comércio ilegal acarreta.

Assim, a partir da justificativa ideológica de combate ao "crime organizado" e ao "narcotráfico", o sistema punitivo busca inspirar a confiança dos setores hegemônicos da sociedade, e, para isso, se rearma na "luta" contra seu alvo preferencial histórico, representado pelas classes subalternas, cujos contingentes crescem assustadoramente diante do avanço do neoliberalismo e da precarização das condições sociais decorrentes de um modelo de Estado cada vez mais cauíla em termos de bem-estar social.

Como destaca Baratta (2000), ao passo que o Estado deixa de garantir a segurança dos direitos de um certo número de "sujeitos" vulneráveis, pertencentes a grupos sociais marginais, a política criminal os reencontra como "objetos" de uma certa forma de política social, que não busca garantir seus direitos, mas sim reforçar a segurança de suas vítimas potenciais.

Hoje, como no período de implantação da ordem burguesa no País, as elites conservadores utilizam-se da disseminação do medo e da insegurança diante da possibilidade do "caos" representado pelo avanço do "crime organizado" e do "narcotráfico", para detonar estratégias de disciplinamento e neutralização das massas empobrecidas. $\mathrm{O}$ que interessava no período da implantação da ordem republicana no Brasil era reprimir a "vadiagem" para garantir 
que a ordem burguesa e a vontade das elites se concretizassem, diante do "medo branco" de uma possível insurreição escrava. Hoje, o que interessa é a manutenção do modelo neoliberal de ordenação da sociedade, e, para tanto, a repressão aos "traficantes" é a justificativa encontrada para a inocuização dos setores que ameaçam esse modelo, porque são absolutamente supérfluos e porque sua existência somente serve para onerar os cofres públicos.

Daí a afirmação de Malaguti Batista (2003a) no sentido de que no Brasil as classes dominantes sempre se utilizaram do medo como estratégia para a derrota das forças populares, associando suas vitórias ao caos e à desordem. Para a referida autora (2005, p. 369),

a difusão do medo do caos e da desordem tem sempre servido para detonar estratégias de disciplinamento e controle das massas populares. $\mathrm{O}$ tipo de ordenamento introduzido pela escravidão em nossa formação sócio-econômica não foi abalado nem pelo fim da escravidão, nem pela República, nem na 'transição democrática' com o fim da ditadura militar implantada após o golpe de 1964.

Portanto, longe de corresponder à plataforma que a sustenta, qual seja, a perseguição dos grandes produtores e comerciantes dos produtos ilícitos, o tráfico de drogas é uma atividade que, por sua grande penetração no imaginário como atividade altamente reprovável, serve de sustentáculo ideológico para o avanço do controle penal sobre os alvos efetivos do sistema (MALAGUTI BATISTA, 2003a). Com isso, o sistema penal brasileiro encontrou "efetivamente, nesse domínio, a nova desculpa para prosseguir com 
a velha batalha." (FLAUZINA, 2008, p. 104).

Demonstra-se, assim, que o fato de o sistema penal brasileiro voltar-se majoritariamente contra os setores subalternos da população para reprimi-los e subjugá-los, infundindo-lhes o terror, serve para garantir a manutenção de uma ordem social pautada em uma rígida hierarquização. Nesse sentido, torna-se possível falar em uma construção imagética do terror da pena e dos agentes do sistema penal, tema objeto do tópico que segue.

\section{CONSIDERAÇOES FINAIS: NOTAS SOBRE A CONSTRUÇÃO IMAGÉTICA DO MEDO DO DIREITO PENAL}

A seletividade que pauta a atuação dos órgãos que integram o sistema penal brasileiro, conforme se procurou evidenciar nos tópicos precedentes, demonstra que a principal função por ele desempenhada na contemporaneidade não é diversa daquela que sempre desempenhou na sociedade brasileira: servir como instrumento de controle e de disciplina das classes subalternas, infundindo-lhes terror, de forma a preservar a segurança e os interesses das classes hegemônicas.

Nesse sentido, torna-se possível também a afirmação de que a difusão contemporânea de imagens de "caos urbano" e de "guerra social generalizada", principalmente pelos meios de comunicação de massa, está associada à necessidade da classe hegemônica exercer o seu poder de dominação das classes subalternizadas. Quer dizer, a hegemonia depende da criação de uma atmosfera de medo dos "pobres", dos "criminosos", dos "negros favelados", enfim, depende da criação da imagem das "classes perigosas", dos "inimigos internos", de forma a justificar, no bojo do discurso do paradigma da segurança cidadã, a necessidade de o sistema punitivo se "rearmar" 
de forma a manter um controle eficiente sobre essa clientela.

A propósito, deve-se levar em consideração o fato de que, como nos lembra Bauman (2009, p. 55), “o 'capital do medo' pode ser transformado em qualquer tipo de lucro político ou comercial", uma vez que "a exposição das ameaças à segurança pessoal é hoje um elemento determinante na guerra pelos índices de audiência dos meios de comunicação de massa (incrementando assim o sucesso dos dois usos, político e mercadológico, do capital medo)."

Dois casos amplamente divulgados pela imprensa nacional servem para ilustrar a forma seletiva e truculenta como o sistema punitivo age em relação aos espólios da escravidão. O primeiro deles refere-se ao caso dos dois irmãos adolescentes negros WilliameCristian Flores, de 17 e 24 anos, respectivamente que, ao se encaminharem ao local onde prestariam o vestibular para o curso de Engenharia Mecânica na Universidade Federal do Rio Grande do Sul, em Porto Alegre, decidiram, a dois quarteirões do prédio, correr para evitar um atraso, uma vez que faltavam poucos minutos para o fechamento dos portões. No entanto, por pertencerem a uma classe considerada "suspeita" e "perigosa" - leia-se: homens adolescentes negros -, no meio do caminho os irmãos foram detidos por três policiais armados, em função do fato de estarem correndo, razão pela qual perderam a prova do vestibular (PETRY, 2005).

Um segundo exemplo, que também constitui um perfeito retrato desta seletividade do sistema punitivo brasileiro, aliada ao tecnicismo jurídico com que se dá a atuação dos seus agentes, encontra-se no documentário Justiça (2004), da diretora Maria Augusta Ramos. Na primeira e impactante cena do filme, a câmera posicionada em uma sala de audiência do Foro Central do Rio de Janeiro presencia um interrogatório cujo "roteiro" parece ter sido concebido por Kafka. O réu, em uma cadeira de rodas, uma perna 
amputada e a outra seriamente comprometida " por um problema nas artérias", responde às perguntas do juiz, atônito diante da acusação pela prática de furto mediante escalada (!). O fato de ter sido preso em "flagrante" pela polícia torna despiciendo afirmar que o acusado se trata de um homem jovem, pobre e negro, que estava passando pelo local onde três "elementos" - essa é a expressão utilizada pelo próprio réu - haviam acabado de furtar uma residência. Ou seja, era muito provável para os agentes policiais que um homem jovem, pobre e negro, ainda que preso a uma cadeira de rodas, fosse o autor do crime de furto qualificado pela escalada do muro da residência.

O juiz, na referida cena, do alto da sua torre de marfim - na expressão de Batista (2002) -, após interromper arbitrariamente a narrativa do réu com um sinal de "pare" com a mão esquerda e um lacônico "tá bom", dita para o escrevente a "versão oficial dos fatos" que integrará os autos do processo. Após perguntar ao acusado "o que você faz da vida", o magistrado traduz a trágica história do acusado, permeada por arbitrariedades e violência policial, da seguinte forma: “que não é verdadeira a acusação (ponto e vírgula) que não praticou o fato narrado na denúncia (ponto e vírgula) que não conhecia os três elementos que passaram correndo."

E o encerramento apoteótico da cena, antes de aparecer com letras garrafais no centro da tela a palavra que dá nome ao documentário, ocorre quando o juiz finalmente se dá conta da situação do acusado: ao pedir ao magistrado "autorização" para transferência para um hospital, visto que estava em uma cela superlotada (79 presos) do "xadrez", onde sequer conseguia evacuar sem ser humilhado pelos companheiros de cela - porque precisava se arrastar pelo chão -, o réu é inquirido pelo juiz: “o que você tem, tá doente?”. Após tomar ciência do estado de saúde do réu - e mais: saber que ele já se encontrava naquele estado quando da sua prisão em "flagrante" - 
o juiz salienta a necessidade de recomendação médica para que ele possa deferir a requerida remoção para um hospital, premiando os espectadores com a frase: "isso é assunto médico, não é assunto de juiz".

Os referidos exemplos servem para demonstrar que a construção de estereótipos e a criação de uma atmosfera de medo ao seu redor configura um instrumento de criação de consenso em torno das práticas do bloco dominante do poder, que permite a reprodução, no marco da escala de valores dominantes, das relações de (re) produção do status quo social brasileiro. Trata-se de um discurso que parte da ideia da existência do "caos", apontando para a necessidade de restabelecimento da "ordem", colocando como pressuposto para a consecução deste objetivo a "guerra" contra os responsáveis pela desordem.

E, em um ambiente de "guerra", concessões à violência do Estado contra os "inimigos" são feitas, o que leva Copetti (2000, p. 66) a asseverar que

as lesões, os homicídios, as sevícias, os tormentos, as torturas, os castigos físicos, as violências sexuais, praticadas quando os perseguidos encontram-se nas mãos do Estado, revelam a existência de uma violência institucionalizada, cujo ocultamento torna-se cada vez mais uma atividade de extrema dificuldade para os componentes do establishment estatal penal. Dentre estes fatos, o mais notório é a morte, e a deslegitimação do discurso e do sistema penal por ele proporcionada ultrapassa os limites teóricos, não só pela sua fácil percepção, mas, principalmente, porque atinge diretamente a 
consciência ética humanista.

Em um contexto tal, assevera Batista (1997b, p. 129), tornase possível falar em uma "política criminal com derramamento de sangue", afinal, quando se constata que a polícia executa, mensalmente, um número constante de pessoas, bem como que ditas pessoas possuem uma mesma extração social, faixa etária e etnia, "não se pode deixar de reconhecer que a política criminal formulada para e por essa polícia contempla o extermínio como tática de aterrorização e controle do grupo social vitimizado."

Efetivamente, os setores estigmatizados da população brasileira são as principais vítimas das políticas de "lei e ordem" e de "caça ao inimigo", o que resta claro a partir da forma como ocorrem as incursões policiais nos bairros populares e o clima bélico que lhes subjaz, tornando possível equipará-las às invasões militares contra um território estrangeiro ou uma zona de guerra. Por meio dessas operações policiais, o Estado busca reafirmar sua autoridade com intensidade, e para esse objetivo vale tudo: tropas derrubando portas de casas e intimidando seus moradores ao atirar indiscriminadamente, escolas fechadas, humilhações públicas e prisões ilegais, execuções sumárias, restrições arbitrárias à livre circulação, etc, tudo ao som de "cânticos de guerra" do tipo daqueles entoados pelo Batalhão de Operações Especiais da Polícia carioca, trazidos ao conhecimento do “grande público" por Soares et al (2006, p. 8):

Homem de preto, qual é sua missão?

É invadir favela

e deixar corpo no chão. 


\section{Alegria alegria, \\ sinto no meu coração, \\ pois já raiou um novo dia, \\ já vou cumprir minha missão. \\ Vou me infiltrar numa favela \\ com meu fuzil na mão, \\ vou combater o inimigo, \\ provocar destruição.}

Diante deste contexto, Neder (1994) salienta que a difusão de imagens do terror como espetáculos de sangue é fundamental para a disseminação do medo. Para a referida autora (1994), o sistema penal brasileiro sempre trabalhou com a produção imagética do terror, o que pode ser visto como uma "bagagem" das imagens de morte e terror trazidas pela Inquisição ibérica.

Essas imagens constroem alegorias do poder que garantem uma forma de organização social rígida e hierarquizada, na qual "as classes subalternas mais que compreender, a nível da razão, foram (e seguem sendo) levadas a ver e a sentir o seu lugar na estrutura social." (NEDER, 1994, p. 9). Quer dizer, alegorias do poder são construídas por meio das imagens para difusão de medo e terror. E é justamente em virtude disso que "os novos inimigos da ordem pública (ontem terroristas, hoje traficantes) são submetidos diuturnamente ao espetáculo penal, às visões de terror dos motins penitenciários e dos corredores da morte." (MALAGUTI BATISTA, 2003a, p. 84).

Neder (1994, p. 20) faz uma interpretação analógica entre os efeitos de internalização ideológica da teatralidade do poder nas praças públicas - a exemplo dos autos de fé da Inquisição com o papel desempenhado na contemporaneidade pela imprensa 
sensacionalista que explora, estampando-o em bancas de jornais, o terror dos corpos mutilados:

se os autos-de-fé constituíram-se em momentos de purificação da fé, representavam também situações onde expunham-se as atrocidades possíveis de serem praticadas (mutilações, fogueiras, etc) geralmente contra grupos étnicoculturais marginalizados, excluídos (judeus, hereges e bruxas). Presentemente, pensamos que à medida em que as estratégias de controle social autoritárias, que organizavam o modus vivendi na cidade e o modus operandi nas instituições de controle social formal (Polícia e Justiça), vêmse esgotadas com o alargamento das conquistas democráticas, esta imprensa sensacionalista está a cumprir um papel inibidor-repressivo, exibindo um horror cotidiano. Com a produção imagética do terror apresentando diariamente mutilações e com a presença de um discurso minudente, detalhista, das atrocidades sofridas pelo 'condenado', a banca de jornal como a praça oferece às classes subalternas, comprovadamente consumidoras preferenciais desta imprensa sensacionalista (de mau gosto para as elites), elementos de controle social informal, de alguma forma eficaz.

Se as classes subalternas vêm avançando e ocupando os espaços públicos destinados somente aos "incluídos", é necessário impor limites, mostrar a que elas estão sujeitas caso insistam em 
ultrapassar as fronteiras socialmente instituídas, enfim, mostrar-lhes que seguem rígidas as barreiras da hierarquização social.

A imposição do medo do Direito Penal cumpre, portanto, com essa função, diante de uma realidade social pautada por aquilo a que Bauman (2009) denomina de "mixofobia" - medo de misturar-se -, muito bem ilustrada, no Brasil, a partir de episódios como os famosos "arrastões" nas praias cariocas na década de 1990, assim como de fatos isolados e sui generis, como, por exemplo, a "invasão" de um shopping center carioca por integrantes do Movimento dos Trabalhadores SemTeto no ano 2000.2 A forma como ditas "invasões" desses espaços "seguros" destinados aos "consumidores" foram tratados pelas autoridades de segurança e pela mídia é um exemplo de como o sistema penal reage diante de eventuais afrontas à ordem pelas classes subalternas, impondo-lhes o medo como forma de mantê-las no lugar que lhes foi destinado pela estrutura social.

Da mesma forma, eventos como aquele que ficou conhecido como o "Massacre do Carandiru", em 1992, que resultou na morte de 111 presos da casa de Detenção de São Paulo, e as recentes e constantes invasões de favelas cariocas em nome da "guerra contra os traficantes", demonstram que a violência e a truculência por parte dos agentes do sistema penal são legitimadas quando se trata de imposição da "ordem" às classes subalternas.

E o espetáculo produzido pela mídia em torno do terror produzido pelo sistema penal diante desses casos serve para produzir efeitos de intimidação e desmobilização política sobre essa população, razão pela qual a mídia pode ser vista, no Brasil, como um grande instrumento de propaganda do sistema penal, sendo, portanto, elemento indispensável para o seu exercício de poder.

2 Para uma visão mais completa de como ditos episódios foram tratados pela mídia e pelo sistema punitivo, ver Malaguti Batista (2003a). 
Desse modo, trabalhando com o "capital do medo", os meios de comunicação de massa são responsáveis pelo desencadeamento de campanhas de "lei e ordem" sempre que o poder configurador do sistema punitivo encontra-se ameaçado.

Assim, ao demonstrar às classes subalternas aquilo a que elas estão sujeitas, o sistema punitivo, por meio de um "ritual de reforço" ${ }^{3}$ que inclui a sua divulgação ad nauseam pela mídia, traz às consciências populares as diferenças necessárias às rotinas sociais em situações em que a igualdade é intolerável (DAMATTA, 1997).

Se se acredita que existe uma "ordem" de verdade na qual cada um tem o seu lugar social demarcado, a produção imagética do terror do Direito Penal acaba por revelar sua real e repugnante função: perseguição, controle e estigmatização das camadas subalternas da população.

3 Para DaMatta (1997), os ritos de ordem ou de reforço são aqueles em que são celebradas relações sociais, mantendo-se suas diferenças e hierarquias. Tais rituais reforçam de forma taxativa quem são os atores e espectadores, e não há a menor possibilidade de troca de lugares. 


\section{Referências Bibliográficas}

ANDRADE, Vera Regina Pereira de. A ilusão de segurança jurídica: do controle da violência à violência do controle penal. Porto Alegre: Livraria do Advogado, 1997.

BARATTA, Alessandro. La política criminal y el derecho penal de la constitución: nuevas reflexiones sobre el modelo integrado de las ciencias penales. Revista Brasileira de Ciências Criminais. São Paulo: Revista dos Tribunais, 2000. n. 29. p. 27-52.

BATISTA, Nilo. Os sistemas penais brasileiros. In. ANDRADE, Vera Regina Pereira de (org.). Verso e reverso do controle penal: (des) aprisionando a sociedade da cultura punitiva. vol. 1. Florianópolis: Fundação Boiteaux, 2002. p. 147-158.

- A violência do Estado e os aparelhos policiais. Discursos sediciosos: crime, direito e sociedade. Rio de Janeiro: Instituto Carioca de Criminologia, 1997a. n. 4. p. 145-154.

- Política criminal com derramamento de sangue. Revista Brasileira de Ciências Criminais. São Paulo: Revista dos Tribunais, 1997b. n. 20.

BAUMAN, Zygmunt. Vidas desperdiçadas. Rio de Janeiro: Jorge Zahar, 2005.

. Confiança e medo na cidade. Rio de Janeiro: Jorge Zahar, 2009. 
CARVALHO, José Murilo de. Cidadania no Brasil: o longo caminho. 4. ed. Rio de Janeiro: Civilização Brasileira, 2003.

CHALHOUB, Sidney. Trabalho, lar e botequim: o cotidiano dos trabalhadores no Rio de Janeiro da belle époque. 2. ed. Campinas: UNICAMP, 2001.

- Cidade febril: cortiços e epidemias na Corte Imperial. São Paulo: Companhia das Letras, 1996.

COPETTI, André. Direito Penal e Estado Democrático de Direito. Porto Alegre: Livraria do Advogado, 2000.

DAMATTA, Roberto. Carnavais, malandros e heróis: para uma sociologia do dilema brasileiro. 6. ed. Rio de Janeiro: Rocco, 1997.

DORNELLES, João Ricardo W. Conflito e segurança: entre pombos e falcões. 2. ed. Rio de Janeiro: Lumen Juris, 2008.

FLAUZINA, Ana Luiza Pinheiro. Corpo negro caído no chão: o sistema penal e projeto genocida do Estado brasileiro. Rio de Janeiro: Contraponto, 2008.

HOLANDA, Sérgio Buarque de. Raízes do Brasil. 26. ed. 28. reimpr. São Paulo: Companhia das Letras, 2007.

HULSMAN, Louk; CELIS, Jacqueline Bernat de. Penas perdidas: o sistema penal em questão. Trad. Maria Lúcia Karam. Niterói: LUAM, 1993. 
JUSTIÇA. Direção: Maria Augusta Ramos. Produção: Luís Vidal, Niek Koppen, Jan de Ruiter e Renée Van der Grinten. Edição: Virgínia Flores, Maria Augusta Ramos e Joana Collier. [São Paulo: Mais Filmes], 2004. 2 DVD (100 min).

MALAGUTI BATISTA, Vera. O medo na cidade do Rio de Janeiro: dois tempos de uma história. 2. ed. Rio de Janeiro: Revan, 2003a.

. Você tem medo de quê? Revista Brasileira de Ciências Criminais. São Paulo: Revista dos Tribunais, 2005. n. 53. p. 367-378.

NEDER, Gizlene; CERQUEIRA FILHO, Gisálio. Criminologia e Poder Político: sobre direitos, história e ideologia. Rio de Janeiro: Lumen Juris, 2006.

NEDER, Gizlene. Em nome de Tânatos, aspectos do sistema penitenciário no Brasil. In. NEDER, Gizlene. Violência e cidadania. Porto Alegre: Sergio Antonio Fabris, 1994. p.11-34.

. Discurso jurídico e ordem burguesa no Brasil. Porto Alegre: Sergio Antonio Fabris, 1995.

. Iluminismojurídico-penal luso-brasileiro: obediência e submissão. 2. ed. Rio de Janeiro: Revan, 2007.

- Cultura, poder e violência. Revista Latinoamericana de Psicopatologia Fundamental. São Paulo, 2009. n. 1. p. 17-30.

PETRY, André. Negro correndo? É ladrão.... Disponível em: < http:// veja.abril.com.br/260105/andre_petry.html>. Acesso em 2 jun. 2010. 
SOARES, Luiz Eduardo; BATISTA, André; PIMENTEL, Rodrigo. Elite da tropa. Rio de Janeiro: Objetiva, 2006.

STRECK, Lenio Luiz. Tribunal do júri: símbolos e rituais. 3. ed. Porto Alegre: Livraria do Advogado, 1998.

. Hermenêutica jurídica e (m) crise: uma exploração hermenêutica da construção do Direito. 8. ed. rev. e atual.. Porto Alegre: Livraria do Advogado, 2008.

WACQUANT, Loïc. Punir os pobres: a nova gestão da miséria nos Estados Unidos [A onda punitiva]. Trad. Sérgio Lamarão. 3. ed. rev. ampl. Rio de Janeiro: Revan, 2007.

WEBER, Max. Economia y sociedad. Trad. José Medina Echavarría e outros. 2. ed. 13. reimpr. México: Fondo de Cultura Econômica, 1999.

ZAFFARONI, Eugenio Raúl. Em busca das penas perdidas. Trad. Vania Romano Pedrosa e Amir Lopez da Conceição. 5. ed. Rio de Janeiro: Revan, 2001. 